\title{
The impact of rhino poaching on tourist experiences and future visitation to National Parks in South Africa
}

Berendien Anna Lubbe*, Elizabeth Ann du Preez, Anneli Douglas and Felicite Fairer-Wessels Tourism Management Division, University of Pretoria, Pretoria, P O Box X20, Hatfield 0028, South Africa

\section{Abstract}

Wildlife tourism attracts substantial numbers of tourists world-wide with Africa as the major wildlife viewing destination earning the bulk of its tourism revenue from such tourism. Iconic animals, such as the rhino, are major attractions for tourists to South Africa who holds approximately $80 \%$ of the World's rhino population. However the rapid increase in rhino poaching activities has reached a crisis point and should the rate of poaching continue to increase Africa's remaining rhino population will become extinct in the wild within 20 years. How this affects tourists and tourism is still largely unknown. This study shows evidence that rhino poaching and anti-poaching measures do impact tourism in the short term and could affect future visitation to Parks.

\section{Key words}

Wildlife tourism, rhino poaching, impact, South Africa

\section{Introduction}

Natural areas, heritage sites and attractions rely heavily on tourism revenue for the conservation of protected areas, the creation of opportunities for historical interactions and for the improvement of economic and social environments (Cetin 2015; Cetin 2016; Cetin \& Sevik, 2016). One form of nature-based tourism that attracts substantial numbers of tourists world-wide is wildlife tourism, with Africa being the major wildlife viewing destination and beneficiary of this form of tourism. International tourism to Africa reached record levels in 2013, with 56 million tourists bringing in R410bn (UNWTO, 2015). Significantly, $80 \%$ of these tourists travel to view the continent's wildlife with a projected economic injection of $10 \%$ per annum, provided poachers are curbed. Should poaching of 
iconic species such as the rhino continue to accelerate at its current rate, Africa's remaining rhino population will become extinct in the wild within 20 years (Biggs, Courchamp Martin \& Possingham, 2013). Wildlife tourism is all about "being able to experience animals in the wild, to observe their "natural' behaviour, and to appreciate their beauty" (Tapper, 2006). Ballantyne, Packer and Sutherland (2011) suggest that the sensory and emotional nature of the wildlife experience and desire to "reconnect with nature" drives wildlife tourism. The public's attention tends to focus on particularly larger species with dramatic behaviour - such as predators, certain iconic animals, or rare and exotic species (Skibins, Hallo, Sharp \& Manning, 2012). In South Africa the iconic 'Big Five', as large charismatic megafauna, function as flagship species and form the foundation of the wildlife tourism experience. South Africa has the largest population of wild rhino and is home to roughly $80 \%$ of the world's remaining rhinos (about 20,405 white and 5,055 black rhino) but is currently experiencing the worst poaching crisis in history, with rhinos being killed daily. During 2015 1,175 rhinos were poached in South Africa, representing a 5,000\% increase in rhino poaching since 2007 (https://www.savetherhino.org). Research on rhino poaching has mainly focused on the ecological implications (Buscher \& Ramutsindela, 2015; Ferreira et al, 2015, Biggs et al, 2013;) with research on the effects of poaching on wildlife tourism limited (Naidoo, Fisher, Manica \& Balmford, 2016; Sebele, 2010). According to the UNWTO (2015) the long term effects of poaching on tourism may be devastating from an economic, social and ecological perspective and since tourists associate Africa with the Big Five, not being able to experience these animals would result in tourist decline with severe economic implications for profit, taxes and contribution to GDP. A reduction in tourism will mean less employment for local communities involved in the accommodation, restaurant and guiding sectors, greater social inequality and escalating costs for the wildlife experience with a potential lack of value for money. In the short term, 
the tourist experience may be affected by poaching and anti-poaching activities. This study investigates the impact of rhino poaching on tourism in terms of tourists' experiences and their decisions on future visits.

\section{Research methodology}

There is a difference between nature tourists and wildlife tourists; where the former is focused on the enjoyment of nature as a holistic feature and the latter on observing wildlife as primary motivation (Chan \& Baum, 2007; Curtin, 2010; Reynolds \& Braithwaite, 2001). Wildlife tourists can be categorised based on specific characteristics derived from values which include a primary interest in wildlife; a strong affection to individual animals; concern for the right and wrong treatment of animals; and concern for the value of animals (Kellert, 1980 in Reynolds \& Braithwaite, 2001). Wildlife tourists (as opposed to tourists that see wildlife- watching as mere part of a relaxing and typical holiday) tend to possess a strong environmental ethic, focus on intrinsic motivations and have the desire to show their dedication to the cause (Curtin, 2010). Visitors to South Africa's most prominent game reserves are typically regarded as wildlife tourists since the primary motivation for travel is to view wildlife in their natural habitat. For this study a convenience sample was drawn from both day and overnight visitors, domestic and international, to the Kruger National Park (SANParks) and Hluhluwe-iMfolozi (Ezemvelo-KZN-Natal Wildlife) Game Reserve with a total of 173 responses being obtained. Questionnaires were used to collect the data with fieldworkers applying the questionnaire personally to each respondent. The questionnaire consisted of both closed and open-ended questions developed from literature on typical characteristics of wildlife tourists, their behaviour, beliefs and opinions on the issue of rhino poaching, the effects of specific rhino poaching scenarios as well as current and future measures to combat poaching on their experience. 


\section{Data analysis}

Quantitative data analysis compared the effects of poaching and anti-poaching activities between various visitor categories based on: location (Kruger/Hluhluwe-iMfolozi); personal opinion (close to my heart/concerned but can't do anything/other); origin (domestic/international); overnight status (day/overnight); frequency of visit (once a year/25 times a year/extensive throughout the year/every 2-5 years/not often/first time); last visit (recent; 1-3 years ago/4+ years ago); personally affected (yes/no); type of contribution (e.g. money/souvenirs/volunteering/activism/none); strength of personal opinion. Chi-square tests were conducted at the $95 \%$ confidence level with some results proving significant at the $99 \%$ level. Content analysis was used for open-ended questions where common themes were sought.

\section{Results and discussion}

Overall, international tourists were found to be less aware of the effect of rhino poaching on the rhino population than were domestic visitors $(\chi 2=9.371, \mathrm{p}<.01)$. This result presents specific opportunities for SANParks and Ezemvelo-KZN Wildlife since international tourists are a powerful voice in conservation (the Kruger National Park alone has approximately 500,000 international visitors annually) and through a greater awareness and deeper understanding, rhino poaching can be more effectively combatted. This conclusion is supported by the result that visitors (both international and domestic) with strong opinions on the poaching issue also exhibited greater knowledge of the numbers of rhinos poached $(\chi 2=12.529, \mathrm{p}<.01)$ and which is the most endangered of the species $(\chi 2=14.289, \mathrm{p}<.05)$. Significantly, these visitors also believed that not enough was being done to combat poaching $(\chi 2=10.945, \mathrm{p}<.05)$. Information on the poaching crisis is deemed sensitive by Parks management but information remains an essential tool to effectively combat poaching by creating awareness and, as such, requires careful planning and dissemination. 
The potential effects of two poaching scenarios namely, seeing a rhino carcass in the bush and seeing a poacher, on visitor experiences and behaviour in relation to the respective visitor categories, were tested. The potential effects included 'loss of enjoyment', 'uncertainty about personal safety', 'domination of conversation during the visit', 'making travel companions unsettled', 'raising questions in my mind', 'not deter me from intended activities', 'raising doubt about future visits to the park', 'a desire to better understand the issue of poaching', 'placing an urgency on future visits., and 'stop me from coming back to the park'. Table 1 indicates the two scenarios along with the specific visitor groups within categories that differed significantly in terms of the possible effects on experiences and behaviour. The cells in columns 2 and 3 indicate the visitor categories significantly affected by the poaching scenarios (with the specific group and test statistic in italics), while column 1 indicates the possible consequence on the experience and visitor behaviour. For example, on seeing a rhino carcass, annual visitors experienced significantly higher levels of doubts about future visits; while doubts about future visits would be significantly more likely among visitors who have been personally affected (thus in terms of the effect 'doubt about future visits to the park', two visitor categories presented significant differences between visitor groups namely frequency of visit and personal history of being affected by rhino poaching, in terms of both poaching scenarios). In terms of the effect of not returning to the park, international visitors and frequent visitors that see a poacher (or what is perceived to be a poacher) would be significantly more inclined to not return to the park (thus in terms of the effect of not returning, only seeing a poacher would create significantly different responses within two categories, namely origin and frequency of visit). The implication of these results (and others in Table 1) for wildlife tourism to the parks in the short-term must be regarded as serious since these categories of visitors provide a main source of funding for conservation in 
SANParks.

Four anti-poaching activities on visitor experiences and behaviour were also tested. These included regular helicopters overhead, vehicles being tagged, vehicles being searched in camps, and road blocks throughout the park. The possible effects on experience and behaviour included that it would spoil chances of game viewing, hinder freedom of movement, lead to loss of enjoyment, create uncertainty about personal safety, dominate conversation during the visit, make travel companions unsettled, raise questions in the mind of the visitor, not deter the visitor from intended activities, raise doubt about future visits to the park, create a desire to understand the issue of poaching, place an urgency on future visits, and stop the visitor from coming back to the park. Similar to Table 1, Table 2 highlights the visitor categories that presented significant results. In terms of the serious effect of deterring the visitor from returning to the park, for example, three of the four antipoaching activities presented significant differences in certain visitor categories. Day as well as frequent visitors are significantly more inclined to not return if exposed to helicopters flying overhead (thus the two visitor categories of overnight status and frequency of visit). Visitors that make monetary contributions toward the cause of rhino poaching are significantly more inclined than other types of contributors to not return if exposed to vehicles being searched in camps. Lastly, visitors that have visited the park more than four years ago are significantly more inclined to not return if exposed to road blocks throughout the park.

In most instances, significant differences between visitor groups related to feelings of discomfort (taking away enjoyment, spoiling chances of game viewing, creating uncertainty 
Table 1: The possible effect of poaching activities on visitor experience and behaviour

\begin{tabular}{|c|c|c|}
\hline $\begin{array}{l}\text { Possible effect on visitor } \\
\text { experience and behaviour }\end{array}$ & $\begin{array}{l}\text { Seeing rhino carcass in } \\
\text { the bush }\end{array}$ & Seeing a poacher \\
\hline $\begin{array}{l}\text { Stop me from coming back to the } \\
\text { park }\end{array}$ & 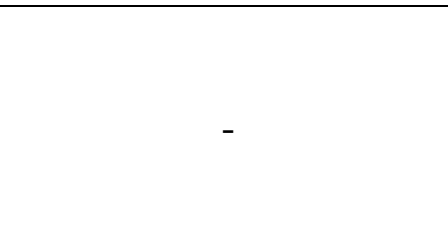 & $\begin{array}{l}\text { Origin (International; } \\
\chi^{2}=11.955^{*} \text { ) } \\
\text { Frequency of visit } \\
\text { (extensive throughout year; } \\
\chi^{2}=19.916^{* *} \text { ) }\end{array}$ \\
\hline $\begin{array}{l}\text { Raise doubt about future visits to } \\
\text { the park }\end{array}$ & $\begin{array}{l}\text { Frequency of visit } \\
\left.\text { (annual; } \chi^{2}=20.725 * *\right)\end{array}$ & $\begin{array}{l}\text { Personally affected (yes; } \\
\left.\chi^{2}=16.018^{*}\right)\end{array}$ \\
\hline Place urgency on future visits & $\begin{array}{l}\text { Overnight status } \\
\text { (overnight; } \chi 2=6.192 * * \text { ) } \\
\text { Frequency of visit (every } \\
2-5 \text { years; } \chi 2=19.926 * * \text { ) }\end{array}$ & $\begin{array}{l}\text { Frequency of visit (annual; } \\
\chi^{2}=25.222 * \text { ) }\end{array}$ \\
\hline $\begin{array}{l}\text { Raise many questions in my } \\
\text { mind }\end{array}$ & 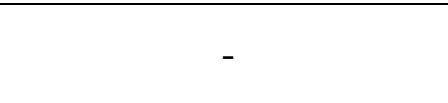 & $\begin{array}{l}\text { Overnight status } \\
\text { (overnight; } \chi 2=6.771 * * \text { ) }\end{array}$ \\
\hline $\begin{array}{l}\text { Create desire to learn more about } \\
\text { the issue }\end{array}$ & $\begin{array}{l}\text { Frequency of visit } \\
\text { (annual; } \chi 2=19.095 * *)\end{array}$ & - \\
\hline $\begin{array}{l}\text { Not deter me from intended } \\
\text { activities }\end{array}$ & ( & $\begin{array}{l}\text { Overnight status } \\
\text { (overnight; } \chi 2=5.991 * * \text { ) } \\
\text { Personally affected (yes; } \\
\chi 2=9.084 * * \text { ) }\end{array}$ \\
\hline
\end{tabular}

Table 2: The possible effect of anti-poaching activities on visitor experience and behaviour

\begin{tabular}{|c|c|c|c|c|}
\hline $\begin{array}{l}\text { Possible effect on } \\
\text { visitor experience } \\
\text { and behaviour }\end{array}$ & $\begin{array}{l}\text { Helicopter } \\
\text { overhead }\end{array}$ & $\begin{array}{l}\text { Vehicle } \\
\text { tagged }\end{array}$ & $\begin{array}{l}\text { Vehicle } \\
\text { searched in } \\
\text { camps }\end{array}$ & $\begin{array}{c}\text { Road blocks } \\
\text { throughout } \\
\text { park }\end{array}$ \\
\hline $\begin{array}{l}\text { Stop me from coming } \\
\text { back to the park }\end{array}$ & $\begin{array}{l}\text { Overnight } \\
\text { status (day; } \\
\chi 2=8.219 * * \text { ) } \\
\text { Frequency of } \\
\text { visit ( } \text { annual } \\
\text { and extensive } \\
\text { throughout } \\
\text { year; } \\
\chi 2=18.369 * * \text { ) }\end{array}$ & - & 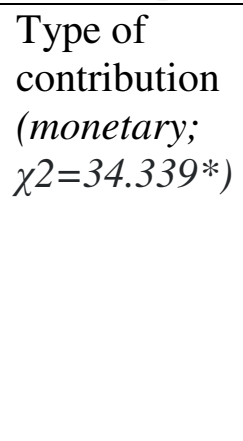 & $\begin{array}{l}\text { Last visit }(4+ \\
\text { years ago; } \\
\left.\chi^{2}=13.455^{* *}\right)\end{array}$ \\
\hline $\begin{array}{l}\text { Raise doubt about } \\
\text { future visits to the } \\
\text { park }\end{array}$ & $\begin{array}{l}\text { Origin } \\
\text { (domestic; } \\
\chi^{2=7.012 * *)}\end{array}$ & - & - & $\begin{array}{l}\text { Personally } \\
\text { affected (yes; } \\
\left.\chi^{2}=6.114 * *\right)\end{array}$ \\
\hline $\begin{array}{l}\text { Place urgency on } \\
\text { future visits }\end{array}$ & $\begin{array}{l}\text { Personally } \\
\text { affected (yes; } \\
\left.\chi^{2}=8.084 * *\right)\end{array}$ & - & $\begin{array}{l}\text { Type of } \\
\text { contribution } \\
\text { (share in the } \\
\text { media; } \\
\chi^{2}=28.152 * \text { ) }\end{array}$ & $\begin{array}{l}\text { Origin } \\
\text { (domestic; } \\
\left.\chi^{2}=7.784 * *\right)\end{array}$ \\
\hline
\end{tabular}




\begin{tabular}{|c|c|c|c|c|}
\hline & & & $\begin{array}{l}\text { Personally } \\
\text { affected (yes; } \\
\left.\chi 2=7.106^{* *}\right)\end{array}$ & \\
\hline $\begin{array}{l}\text { Raise many questions } \\
\text { in my mind }\end{array}$ & $\begin{array}{l}\text { Personally } \\
\text { affected (yes; } \\
\left.\chi^{2}=8.211^{* *}\right)\end{array}$ & - & $\begin{array}{l}\text { Personally } \\
\text { affected (yes; } \\
\left.\chi^{2}=7.138^{* *}\right)\end{array}$ & $\begin{array}{l}\text { Last visit }(4+ \\
\text { years ago; } \\
\left.\chi^{2}=11.258^{* *}\right) \\
\text { Personally } \\
\text { affected (yes; } \\
\left.\chi^{2}=10.886^{*}\right)\end{array}$ \\
\hline $\begin{array}{l}\text { Uncertain about } \\
\text { personal safety }\end{array}$ & 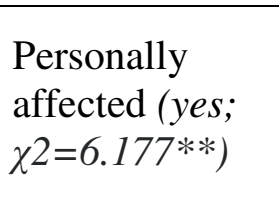 & $\begin{array}{l}\text { Opinion about } \\
\text { issue } \\
\text { (concerned; } \\
\left.\chi^{2}=12.265 * *\right)\end{array}$ & $\begin{array}{l}\text { Personally } \\
\text { affected (yes; } \\
\left.\chi^{2}=6.058 * *\right)\end{array}$ & $\begin{array}{l}\text { Last visit }(4+ \\
\text { years ago; } \\
\left.\chi^{2}=11.033^{*} *\right)\end{array}$ \\
\hline $\begin{array}{l}\text { Hinder freedom of } \\
\text { movement }\end{array}$ & $\begin{array}{l}\text { Personally } \\
\text { affected (yes; } \\
\left.\chi^{2}=8.661^{* *}\right)\end{array}$ & $\begin{array}{l}\text { Opinion about } \\
\text { issue (close to } \\
\text { heart; } \\
\left.\chi^{2}=10.048 * *\right)\end{array}$ & $\begin{array}{l}\text { Last visit } \\
\text { (recent; } \\
\left.\chi^{2}=9.772 * *\right)\end{array}$ & - \\
\hline $\begin{array}{l}\text { Spoil chances of game } \\
\text { viewing }\end{array}$ & $\begin{array}{l}\text { Location } \\
(K N P ; \\
\left.\chi^{2}=7.508 * *\right)\end{array}$ & $\begin{array}{l}\text { Opinion about } \\
\text { issue (close to } \\
\text { heart; } \\
\left.\chi^{2}=10.800 * *\right)\end{array}$ & - & - \\
\hline Take away enjoyment & $\begin{array}{l}\text { Frequency of } \\
\text { visit (extensive } \\
\text { throughout } \\
\text { year; } \\
\chi^{2}=24.689^{*} \text { ) }\end{array}$ & $\begin{array}{l}\text { Origin } \\
\text { (domestic; } \\
\left.\chi^{2}=9.065^{*}\right)\end{array}$ & $\begin{array}{l}\text { Frequency of } \\
\text { visit } \\
\text { (nfrequent; } \\
\chi 2=19.757 * * \text { ) }\end{array}$ & $\begin{array}{l}\text { Opinion about } \\
\text { issue (other; } \\
\chi^{2}=11.855^{*} \text { ) } \\
\text { Personally } \\
\text { affected (yes; } \\
\left.\chi^{2}=7.618^{*} *\right)\end{array}$ \\
\hline $\begin{array}{l}\text { Make travel } \\
\text { companions unsettled }\end{array}$ & - & - & - & $\begin{array}{l}\text { Origin } \\
\text { (international; } \\
\chi 2=7.731 * * \text { ) } \\
\text { Frequency of } \\
\text { visit (annual; } \\
\left.\chi^{2}=18.498 * *\right)\end{array}$ \\
\hline $\begin{array}{l}\text { Dominate } \\
\text { conversation during } \\
\text { visit }\end{array}$ & $\begin{array}{l}\text { Personally } \\
\text { affected (yes; } \\
\left.\chi^{2}=6.860^{* *}\right)\end{array}$ & - & $\begin{array}{l}\text { Frequency of } \\
\text { visit }(2-5 \text { times } \\
\text { a year; } \\
\chi 2=23.026 *) \\
\text { Type of } \\
\text { contribution } \\
\text { (volunteer/ } \\
\text { activism; } \\
\chi 2=24.849 * *)\end{array}$ & $\pi$ \\
\hline $\begin{array}{l}\text { Not deter me from } \\
\text { intended activities }\end{array}$ & $\begin{array}{l}\text { Origin } \\
\text { (domestic; } \\
\left.\chi^{2}=7.745^{* *}\right) \\
\text { Personally } \\
\text { affected (yes; } \\
\left.\chi^{2}=6.654^{* *}\right)\end{array}$ & $\begin{array}{l}\text { Type of } \\
\text { contribution } \\
\text { (monetary; } \\
\chi^{2=30.174 *)}\end{array}$ & $\begin{array}{l}\text { Opinion about } \\
\text { issue (other; } \\
\chi 2=10.680 * *) \\
\text { Personally } \\
\text { affected (yes; } \\
\chi 2=10.337 * \text { ) }\end{array}$ & - \\
\hline Create desire to learn & Personally & Origin & Type of & - \\
\hline
\end{tabular}




\begin{tabular}{|l|l|l|l|l|}
\hline more about the issue & affected (yes; & (domestic; & contribution & \\
& $\chi 2=10.204 *)$ & $\left.\chi^{2}=7.738 * *\right)$ & $($ none; & \\
& & Frequency of & $\chi 2=31.049 *)$ & \\
& & visit (every 2- & Personally & \\
& & 5 years and & affected (yes; & \\
& & infrequent; & $\chi 2=7.522 * *)$ & \\
& & & \\
& & & \\
& & & \\
\end{tabular}

$* \mathrm{p}<.01$

$* \mathrm{p}<.05$ 
about personal safety); and affecting positive immersion in the experience by raising questions and dominating conversations. Importantly, these measures could have different impacts on future behaviour by placing an urgency on future visits, raising doubts about future visits and even avoiding future visits to the park. In analyzing the open-ended questions relating to suggestions to combat poaching, some common themes emerged such as the use of drones which would not necessarily affect the animals or their own game viewing experience in the Park, decisive actions against poachers, more funding and stricter policies at the higher levels of government, inter-government agencies, the judicial systems as well as the Parks themselves, closing the fence between neighbouring countries, greater border control and stricter penalties (longer sentences) for perpetrators.

\section{Concluding note}

The issue of rhino poaching is emotive and this became evident particularly through the analysis of the qualitative open questions. The research indicated that people in some way want to be involved in the fight against poaching. A strong belief was evident amongst most visitors that not enough is being done to combat poaching that can be viewed against the perceived lack of information provided on the issue. This lack of information leads to speculation and distrust and the perception that the situation is not under control. Supported by other studies (Higham \& Shelton, 2011; Orams, 2002)the implications of rhino poaching on tourism in the short term is, as the study showed, that while a spike in visitation may occur if visitors believe that rhinos will become extinct, there are potentially devastating consequences for future visits if poaching and anti-poaching activities continue to be seen as part of the wildlife experience. A decline in tourists' visits will directly affect tourism revenue which forms the bulk of the funding for conservation and protection of endangered animals. Thus, further urgent research is suggested on critical issues which considers aspects such as the impact of poaching on tourism personnel and operations in the Parks as well as further 
exploration of local communities' understanding of the value of the rhino in terms of its safeguarding for future economic and tourism benefits.

\section{References}

Ballantyne, R., Packer J. \& Sutherland L.A. 2011. Visitors' memories of wildlife tourism: Implications for the design of powerful interpretive experiences. Tourism Management, 32(4):770-779.

Biggs, D., Courchamp, F., Martin, R. \& Possingham, H.P. 2013; Legal Trade of Africa's Rhino Horns. Science, 339 (6123): 1038-1039.

Buscher, B. \& Ramutsindela, M. 2015. Green violence: rhino poaching and the war to save southern Africa's Peace Parks. African Affairs. 115(458): 1-22.

Cetin M. (2015a). Evaluation of the sustainable tourism potential of a protected area for landscape planning: a case study of the ancient city of Pompeipolis in Kastamonu. International Journal of Sustainable Development \& World Ecology, 22(6), 490-495.

Cetin M. (2016). Sustainability of urban coastal area management: a case study on Cide, Journal of Sustainable Forestry, 2016, 35 (7), 527-541.

Cetin M., Sevik H. (2016). Evaluating the recreation potential of Ilgaz Mountain National Park in Turkey. Environmental Monitoring and Assessment, 188(1):52.

Chan, J.K.L. \& Baum, T. 2007. Ecotourists' perceptions of ecotourism experience in 
Lower Kinabatangan, Sabah, Malaysia. Journal of Sustainable Tourism, 15(5):574:590.

Curtin, S. 2010. The self-presentation and self-development of serious wildlife tourists. International Journal of Tourism Research, 12:17-33.

Ferreira SM, Greaver C, Knight GA, Knight MH, Smit IPJ, Pienaar D (2015) Disruption of Rhino Demography by Poachers May Lead to Population Declines in Kruger National Park, South Africa. PLoS ONE 10(6): e0127783. https://doi.org/10.1371/journal.pone.0127783.

Higham, J.E.S. \& Shelton, E.J. 2011. Tourism and wildlife habituation: reduced population fitness or cessation of impact? Tourism Management, 32(6):1290-1298.

Naidoo, R., Fisher, B., Manica, A. \& Balmford, A. 2016. Estimating economic losses to tourism in Africa from the illegal killing of elephants. Nature Communication. 7: 13379.

Orams, M.B. 2002. Feeding wildlife as a tourism attraction: a review of issues and impacts. Tourism Management, 23(3):281-293.

Reynolds, P.C. \& Braithwaite, D. 2001. Towards a conceptual framework for wildlife tourism. Tourism Management, 22:31-42.

Sebele, L.S. 2010. Community-based tourism ventures, benefits and challenges: Khama Rhino Sanctuary Trust, Central District, Botswana. Tourism Management. 31(1): 136-146.

Skibins, J.C., Hallo, J.C., Sharp, J.L. \& Manning, R.E. 2012. Quantifying the Role of Viewing the Denali "Big 5" in Visitor Satisfaction and Awareness: Conservation 
Implications for Flagship Recognition and Resource Management. Human Dimensions of Wildlife, 17(2):112-128.

Tapper, R. 2006. Wildlife watching and tourism: A study on the benefits and risks of a fast growing tourism activity and its impacts on species. [Online] Available from: http://www.cms.int [Accessed: 2013-04-15].

UNWTO 2015. 'Towards Measuring the Economic Value of Wildlife Watching Tourism in Africa', Briefing Paper. UNWTO. 